Nota Científica

\title{
Amazonian açai and food dyes for staining arbuscular- micorrhizal fungi
}

\author{
Aline Lourdes Martins Silva ${ }^{1}$, Marcos Diones Ferreira Santana², John Cesar de Jesus Pereira ${ }^{3}$, Milena Pupo Raimam ${ }^{3}$, \\ Ulisses Brigatto Albino ${ }^{1 *}$

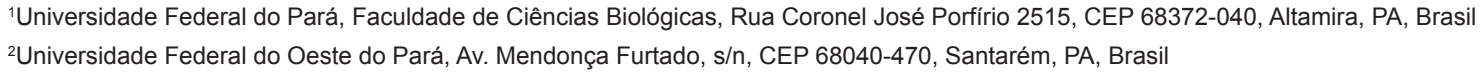

*Autor correspondente:

ualbino@ufpa.br

Termos para indexação:

Corantes naturais

Microbiologia do solo

Euterpe oleracea

Index terms:

Natural dyes

Soil microbiology

Euterpe oleracea

Histórico do artigo:

Recebido em 10/10/2014

Aprovado em 15/12/2015

Publicado em 31/12/2015

doi: $10.4336 / 2015 . p f b .35 .84 .798$

\begin{abstract}
Arbuscular mycorrhizae microscopy requires differential staining of typical structures. Dyes employed, such as trypan blue, pose risks to health and environment. Alternative dyes such as pen ink and aniline have variable coloring efficiency. In this work, Brachiaria decumbens roots, discolored with caustic soda $(\mathrm{NaOH})$, were stained with açai, annatto, saffron, trypan blue and pen inks. There were significant differences among dyes regarding stained mycorrhizal structures and pictures quality. Acai was considered the best alternative dye, with similar results to trypan blue.
\end{abstract}

\section{Açaí da Amazônia e corantes alimentícios para colorir fungos micorrízicos arbusculares}

\begin{abstract}
Resumo - A microscopia de micorrizas arbusculares requer coloração diferencial de estruturas típicas. Corantes usualmente empregados, como trypan blue, oferecem riscos à saúde e ao ambiente. Alternativas como tintas de caneta e anilina têm eficácia de coloração variável. Neste trabalho, raízes de Brachiaria decumbens, descoloridas com soda cáustica $(\mathrm{NaOH})$, foram coradas com açaí, urucum, açafrão, trypan blue e tintas de caneta. Verificou-se diferença significativa entre os corantes quanto às estruturas micorrízicas coradas e a qualidade das imagens fotografadas. Açaí foi considerado o melhor corante alternativo, com resultados similares ao trypan blue.
\end{abstract}

Arbuscular mycorrhizal fungi (AMF) are organisms that associate with plants from different botanical families. They are extensively studied for their ecological role and for representing a promising alternative for agriculture. As obligate symbionts, they bring benefits to plants community and to the environment by providing nutrients and water to the plants, and also by promoting moisture retention, aggregation and stability of the soil (Sylvia, 1992; Augé et al., 2001). Mycorrhizal association is formed by host root, intraradicular mycelium (hyphae, arbuscules and vesicles), extra- radicular mycelium (network of ground hyphae) and spores, which are the fungus reproductive structures (Merryweather \& Fitter, 1998). Besides facilitating the interaction of the plant with the soil, mycorrhizal association mediates the relationship of the plant with other living beings, for example, protecting it from pathogens (Miller \& Kling, 2000). Studies indicate that mycorrhizal fungi had a key role when plants left the sea and colonized the land given their presence in fossils 400 million years (Smith \& Read, 1997). 
There are variations in the degree of interaction between plant and fungus, featuring different types of mycorrhiza. The most studied in the tropics are the arbuscular formed by fungi of Glomales order (Zygomycetes). Arbuscule is a structure of intimate contact between fungus and plant that allows the exchange of organic compounds, minerals and water. The methodologies for studying these structures require separation of fungi spores from soil (Gerdemann \& Nicolson, 1963), the purification of typical substances such as glomalin (Wright \& Upadhyaya, 1996) and especially the visualization of fungal structures in tissues of the host plant. This visualization is done using techniques that discolor the host root and differentially color fungal structures. The most renowned techniques use bases such as $\mathrm{NaOH}$ or $\mathrm{KOH}$ to clarify the roots (Phillips \& Hayman, 1970), with some variations using hydrogen peroxide in the clarification (Koske \& Gemma, 1989) followed by staining of fungal structure using an acid dye.

The pioneering technique (Phillips \& Hayman, 1970) uses trypan blue dye and lactic acid. Despite its efficacy, the technique presents problems such as high cost of the dye, emission of vapors during the boiling process, irritation to eyes and skin, and the proven mutagenicity of trypan blue in the Ames test (Robertson et al., 1982), which may become carcinogenic if decomposed by some bacteria (Chung, 1983). Brundrett et al. (1984) proposed the use of chlorazol black E (CBE), asserting that this is a more efficient compound than trypan blue for staining the arbuscules, the most difficult structures to observe in mycorrhizal associations. This dye, however, is more difficult to acquire than trypan blue, and is also noted as carcinogenic (Combes \& Haveland-Smith, 1982). These factors make mycorrhizae staining technique somewhat dangerous, especially when it comes to soil microbiology laboratory classes, where students handle the solutions. Some effective alternatives have been proposed by Vierheilig et al. (1998) (using regular pen ink) and Grace \& Stribley (1991) (using aniline). Many researchers have joined these techniques that lower costs and increase safety, but in addition to not producing the same results in all tested plants (Vierheilig et al., 2005), the suggested ink brands are not easily found in all countries and may, therefore, cost more than the trypan blue dye or CBE.

In this study, we aim to present to the scientific community our positive results using natural dyes to replace trypan blue, as well as household substances, cheaper and less toxic, as an alternative to other components used in the original technique.

In Brazilian Amazon, especially in the state of Pará, Euterpe oleracea palm fruit, the açai berry, is considered as a valuable food and widely used as natural dye. Anthocyanins that are responsible for the purple color of the fruit (Bobbio et al., 2000) have been tested for use in dentistry (Embrapa Amazônia Oriental, 2004) and in ophthalmic surgical techniques due to the low mucosa and ocular tissues irritability when compared to synthetic dyes (Novais et al., 2013). This was the first natural dye tested. The first experiments were performed in preparations for laboratory classes. $\mathrm{KOH}$ was replaced by caustic soda (low purity $\mathrm{NaOH}$ ) used in household cleaning and soap production. Out of regular pens found in supermarkets, Pilot brand was the only one used. The others, when added to vinegar (acetic acid 4\%) (Vierheilig et al., 1998), coagulate before penetrating the clarified roots. Pilot brand, however, is expensive in Brazilian market. After few trials and optimizations, an experiment was designed to compare the promising dyes available on the local market to trypan blue staining and the efficacy of using caustic soda as a base for root bleaching. The following solutions using solvents such as vinegar were prepared: trypan blue $0.5 \%$, blue pen ink 5\%, red pen ink 5\%, saffron powder (Crocus sativus) 5\%, annatto powder (Bixa orellana) 5\% and açai pulp $5 \%$. Açai, in accordance with previous optimizations, rather than being dissolved in vinegar, was diluted by $5 \%$ pure acetic acid, forming a thick dye.

Grass (Brachiaria decumbens) colonized by mycorrhizal fungus Glomus etunicatum in a vase had their roots cut and washed in water. The roots were immersed in solution of caustic soda $10 \%$ and boiled in water bath (double boiler) for $40 \mathrm{~min}$. After boiling, they were rinsed in running water to remove the $\mathrm{NaOH}$, and immersed for $1 \mathrm{~min}$ in $0.1 \mathrm{~N} \mathrm{HCl}$ solution. Next, they were divided into six test tubes. Each tube received a dye solution and they were boiled in water bath for $5 \mathrm{~min}$. After boiling, the root fragments were rinsed in tap water and immersed in solution of vinegar with $10 \%$ glycerin. From each test tube four slides were assembled for microscopy, each with $5 \mathrm{~cm}$ of roots. Through an optical microscope with 40X magnification, the roots were analyzed subjectively for staining quality, and numerically by counting the mycorrhizal structures (hyphae, vesicles, arbuscules and spores). After calculating the average of the visible structures 
per centimeter of root, the numbers were subjected to analysis of variance after logarithmization $(\log x+1)$, and to the Tukey test at $5 \%$ reliability, considering each dye as a separate treatment.

The best contrast between mycorrhizal structures and plant tissue was obtained with açai dye (Figure 1). Hyphae and vesicles were dyed to a brilliant purple while the plant tissue presented a light pink color. The difference in shades provided better definition of the structures. Blue pen ink showed the same structures as trypan blue, though in less intense shades, making it difficult to differentiate some of these structures. Red pen ink did not highlight the arbuscules. This result may be due to the large distribution variation of structures on the roots, but may also be an incompatibility between the dye and the structure. As Vierheilig et al. (2005) proposed, each brand of pen ink can best stain structures in one plant or another, but arbuscules are particularly difficult to visualize, even when stained with trypan blue (Brundrett et al., 1984).

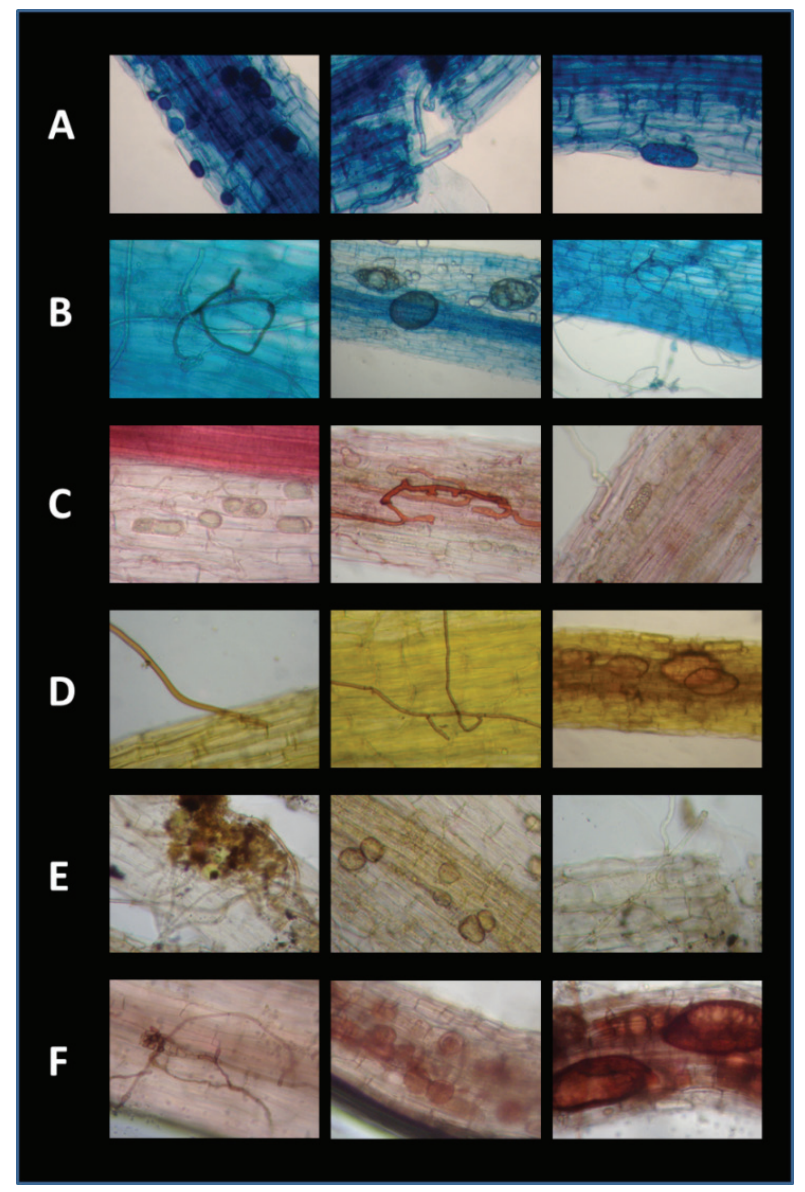

Figure 1. Grass root mycorrhizal featuring structures stained with acetic solutions of A) trypan blue (tree images), B) blue pen ink, C) red pen ink; D) saffron, E) annatto F) açai. (Pictures: Albino, U.)
Saffron and annatto dyes were also effective in coloring fungal structures. However annatto provided variable colors depending on the structure, highlighting internal spores. This may have affected the counting, since in Tukey test (Table 1) this dye was considered more efficient than trypan blue and red pen ink in the spore parameter. The remaining structures were successfully stained, although with lower intensity, and the spots formation on the roots surface hindered internal viewing of some areas. The part of annatto plant (B. orellana) that is used as dye is a red, oily layer that covers the seeds. This feature makes it difficult to solubilize and, consequently, to penetrate the clarified roots. The two pen inks also formed deposits on the roots that, although small, can hide structures and compromise their quantification in tasks that demand greater rigor.

Saffron (C. sativus) is well soluble in water and besides being employed in cooking it is known as a traditional dye for fabrics and leathers. The coloring of the structures with this dye, especially vesicles and spores, was of a golden shade, contrasting with plant tissue that stained to a translucent yellow, which allowed a didactic approach in a class environment. As with roots stained by red pen ink, the ones stained with saffron showed no arbuscules. This result may be due to the absence of these structures or incompatibility with the dye.

Table 1. Average of typical structures of mycorrhizal association (spores, hyphae, vesicles and arbuscules) per centimeter of root, counted on grass roots stained with different dyes.

\begin{tabular}{lcccc}
\hline & \multicolumn{4}{c}{ Fungal estrutures $\left(\right.$ Unit $\left.^{1} \mathrm{~cm}^{-1}\right)$} \\
\cline { 2 - 5 } Dyes & Spores & Hyphae & Vesicles & Arbuscules \\
\hline Trypan blue & $0.55 \pm 0.40 \mathrm{~b}$ & $4.65 \pm 0.77 \mathrm{a}$ & $2.26 \pm 2.07 \mathrm{a}$ & $0.24 \pm 0.28 \mathrm{a}$ \\
Blue ink & $1.57 \pm 0.61 \mathrm{ab}$ & $5.80 \pm 0.92 \mathrm{a}$ & $1.85 \pm 1.11 \mathrm{a}$ & $0.56 \pm 0.83 \mathrm{a}$ \\
Red ink & $0.52 \pm 0.75 \mathrm{~b}$ & $4.57 \pm 1.11 \mathrm{a}$ & $1.95 \pm 1.91 \mathrm{a}$ & $0.00^{*}$ \\
Saffron & $1.38 \pm 1.32 \mathrm{ab}$ & $5.32 \pm 0.67 \mathrm{a}$ & $2.02 \pm 0.55 \mathrm{a}$ & 0.00 \\
Annatto & $2.83 \pm 1.78 \mathrm{a}$ & $5.33 \pm 1.79 \mathrm{a}$ & $3.57 \pm 2.06 \mathrm{a}$ & $0.24 \pm 0.28 \mathrm{a}$ \\
Açai & $1.04 \pm 0.38 \mathrm{ab}$ & $3.99 \pm 1.13 \mathrm{a}$ & $3.43 \pm 1.22 \mathrm{a}$ & $0.40 \pm 0.79 \mathrm{a}$ \\
Anova & $\mathrm{F}=2.861$ & $\mathrm{~F}=1.37$ & $\mathrm{~F}=0.96$ & $\mathrm{~F}=0.252$ \\
& $\mathrm{p}=0.045$ & $\mathrm{p}=0.282$ & $\mathrm{p}=0.468$ & $\mathrm{p}=0.859$ \\
\hline
\end{tabular}

Averages followed by the same letter on the columns do not differ at the $5 \%$ level of significance by the Tukey test. * There were no arbuscules in roots stained with red pen ink or saffron.

Despite the small and non-statistical difference among results obtained with the different dyes, this quantification test refers to the number of structures observed. Regarding the coloring quality, it was 
observed that structures became more evident and presented more homogenous color when roots were stained with açai (Figure 1), making açai the nearest dye to trypan blue in quality. Some references presented in this work (Brundrett et al., 1984; Vierheilig et al., 1998, 2005) warn about the possibility of either of the already tested dyes not highlight any mycorrhizal structures in certain plants or even not highlight certain structures, especially arbuscules, which may lead to erroneous interpretations. For tasks that demand more precision, it is possible to perform a previous test comparing any of these alternative dyes to trypan blue or clorazol black $\mathrm{E}$ and when proven its efficacy, continue to work with them.

With the exception of red pen ink solutions and saffron, with which no arbuscules were observed, all other dyes provided satisfactory results, successfully coloring typical mycorrhizal structures. Each dye however has a higher affinity for one structure or another. This work, therefore, adds to several other works compiled by Vierheilig et al. (2005) that show different possibilities to identify and quantify mycorrhizal structures. This provides the scientific community with options, allowing them to study this important interaction, independent of their geographical location. As açai does not have any quantitative or qualitative problem in staining, its use in research for plants has been proven effective, and should be a replacement for synthetic dyes during soil microbiology classes for the greater safety provided to students and teachers, as well as for the lowering of costs in acquiring reagents commonly used. Being a non-timber forest product, its consumption and use in several applications act as a stimulus to cultivation and sustainable exploration of these fruits, as well as a way to promote the Brazilian Amazonian culture.

\section{Rereferences}

AUGÉ, R. M.; STODOLA, A. J. W.; TIMS, J. E.; SAXTON, A. M. Moisture retention properties of a mycorrhizal soil. Plant and Soil, The Hague, v. 230, p. 87-97, 2001.

BOBBIO, F. O.; DRUZIAN, J. I.; ABRÃO, P. A.; BOBBIO, P. A.; FADELLI, S. Identificação e quantificação das antocianinas do fruto do açaizeiro (Euterpe oleracea) Mart. Ciência e Tecnologia de Alimentos, Campinas, v. 20, n. 3, set./dez. 2000. DOI: 10.1590/ S0101-20612000000300018.

BRUNDRETT, M. C.; PICHE, Y.; PETERSON, R. L. A new method for observing the morphology of vesicular: arbuscular mycorrhizae. Canadian Journal of Botany, Ottawa, v. 62, n. 10, p. 2128 - 2134. 1984. DOI: $10.1139 / \mathrm{b} 84-290$.
CHUNG, K.-T. The significance of azo-reduction in the mutagenesis and carcinogenesis of azo dyes. Mutation Research/Reviews in Genetic Toxicology, Amsterdam, v. 114, n. 3, p. 269-281. 1983. DOI: $10.1016 / 0165-1110(83) 90035-0$.

COMBES, R. D.; HAVELAND-SMITH, R. B. A review of the genotoxicity of food, drug and cosmetic colour and other azo, triphenylmethane and xanthene dyes. Mutation Research/Reviews in Genetic Toxicology, Amsterdam, v. 98, n. 2, p. 101-248, 1982. DOI: 10.1016/0165-1110(82)90015-X.

EMBRAPA AMAZÔNIA ORIENTAL. Composição evidenciadora de placa bacteriana à base de corantes naturais. Belém, PA, 2004. Avaliable at: $<$ http://www.infoteca.cnptia.embrapa.br/handle/ doc/406152>. Accessed: 8 ago. 2014.

GERDEMANN, J. W.; NICOLSON, T. H. Espores of mycorrhizal endogene species extracted from soil by wet-sieving and decanting. Transactions of the British Mycological Society, Cambridge, v. 46, p. 235-244, 1963.

GRACE, C.; STRIBLEY, D. P. A safer procedure for roution staining of vesicular-arbuscular mycorrhizal fungi. Mycological Research, Cambridge, v. 95, n. 10, p. 1160-1162, 1991.

KOSKE, R. E.; GEMMA, J. N. A modified procedure for staining roots to detect VA mycorrhizas. Mycological Research, Cambridge, v. 92 , p. $488-505,1989$.

MERRYWEATHER, J. W.; FITTER, A. The arbuscular mycorrhizal fungi of Hyacinthoides non-scripta. II. Seasonal and spatial patterns of fungal populations. New Phytologist, v. 138, p. 131-142, 1998. DOI: 10.1046/j.1469-8137.1998.00889.x.

MILLER, R. M.; KLING, M. The importance of integration and scale in the arbuscular mycorrhizal symbiosis. Plant and Soil, The Hague, v. 226, n. 2, p. 295-309, 2000. DOI: 10.1023/A:1026554608366.

NOVAIS, E. A.; RODRIGUES, E. B.; FERREIRA, M. A.; CHEN, J.; MAIA, A.; MAIA, M.; BADARÓ, E.; PENHA, F. M.; FARAH, M. E. Natural dyes for chromovitrectomy. Retina Today, p. 33-36, Mar. 2013. Avaliable at: <http://retinatoday.com/2013/03/naturaldyes-for-chromovitrectomy/>. Accessed: 16 ago. 2014.

PHILIPS, D. A.; HAYMAN, D. S. Improved procedures for clearing roots and staining parasitic and vesicular-arbuscular mycorrhizal fungi for rapid assessment of infection. Transactions of the British Mycological Society, Cambridge, v. 55, n. 1, p. 158-161, 1970.

ROBERTSON, J. A.; HARRIS, W. J.; MCGREGOR, D. B. Mutagenicity of azo dyes in the Salmonella/activation test. Carcinogenesis, Oxford, v. 3, n. 1, p. 21-23. 1982. DOI: 10.1093/ $\operatorname{carcin} / 3.1 .21$.

SMITH, S. E.; READ, D. J. Mycorrhizal symbiosis. 2nd ed. London: Academic Press, 1997.

SYLVIA, D. M. Quantification of external hyphae of vesiculararbuscular mycorrhizal fungi. In: NORRIS, J. R.; READ, D. J.; VARMA, A. K. (Ed.). Methods in microbiology: techniques for the study of mycorrhiza. New York: Academic Press, 1992. p. 53-66.

VIERHEILIG, H.; COUGHLAN, A. P.; WYSS, U.; PICHE, Y. Ink and vinegar, a simple staining technique for arbuscular-mycorrhizal fungi. Applied and Environmental Microbiology, Washington, US, v. 64, n. 12 , p. $5004-5007,1998$. 
VIERHEILIG, H.; SCHWEIGER, P.; BRUNDRETT, M. An overview of methods for the detection and observation of arbuscular mycorrhizal fungi in roots. Physiologia Plantarum, Copenhagen, v. 125, n. 4, p. 393-404. 2005. DOI: 10.1111/j.1399-3054.2005.00564.x.
WRIGHT, S. F.; UPADHYAYA, A. Extraction of an abundant extract glomalin from soils of arbuscular mycorrhizal fungi. Soil Science, v. 161, p. 575-586, 1996. DOI: 10.1097/00010694-199609000-00003. 
